\title{
Latin American Christians Living in the Basque Country (Spain): What Remains and What Changes
}

\author{
Lidia Rodríguez *(1), Luzio Uriarte * and Iziar Basterretxea * \\ Faculty of Theology, University of Deusto, 48007 Bilbo, Spain \\ * Correspondence: lidia.rodriguez@deusto.es (L.R.); luzio.uriarte@deusto.es (L.U.); ibaster@deusto.es (I.B.)
}

Received: 29 November 2019; Accepted: 7 February 2020; Published: 12 February 2020

\begin{abstract}
The research we will present is based on interviews conducted with the Latin American immigrant population and the indigenous population of the Basque Autonomous Community (BAC hereafter). We seek to identify religious features tracing similarities and differences between three populations: First, the native community of the BAC, second, Latin American immigrants living in the BAC, and third, Latin Americans in their home countries. In the latter case, we based on the research carried out by Gustavo Morello's team. Analysis of the data obtained so far allows us to compare across two different processes in the Christian religion: On the one hand, the religious experience of Latin Americans in their countries of origin and the religious experience of Latin American immigrants in the BAC; on the other hand, between the latter community and the native population. This paper highlights conclusions referring: (1) The similarities in two significant processes, i.e., religious pluralism and religious autonomy; (2) the differences on religious hybridization, public presence and the use of religious artefacts. In short, it is a contribution to a better understanding of the effects produced on religious experiences in a context marked by secularization and religious pluralism.
\end{abstract}

Keywords: secularization; religious pluralism; religious autonomy; religious experience; Latin American immigration; Basque Autonomous Community

\section{Introduction}

The survey presented here is part of the Lived Religion project entitled "The Transformation of Lived Religion in Urban Latin America: A Study of Contemporary Latin Americans' Experience of the Transcendent", financed by the Templeton Foundation and led by Gustavo Morello (Boston College). The investigation focused on understanding the ways in which religious experience and/or spirituality takes shape among Latin American populations in daily life. In our case, we replicated their survey in a comparative perspective, but on a more limited scale in the Basque Autonomous Community (BAC).

Section 2 is devoted to present some methodological issues regarding Morello's research and to explain the local peculiarities of our survey. Then we will begin Section 3 with a brief quantitative analysis, including a short description of the socio-religious context of the Basque host society. Next, we offer statistical data taken from the Basque public organization Ikuspegi (2018) on the religiousness of the Latin American population living in the BAC. Figures are complemented in Section 4 by the results of qualitative analysis of the twenty-eight in-depth interviews conducted so far with Catholics and Evangelicals.

The section on qualitative analysis is divided into three parts. The first section summarizes the qualitative research of Morello's team and highlights two processes that serve for the purposes of comparison: Autonomy and religious pluralism. The second section compares the findings of the research carried out in Latin America with those obtained from the Latin American interviewees in the BAC. Last, the third section compares the remarks of Latin American immigrants with those of the indigenous population in order to identify similarities and differences between both groups. 
Section 5 provides a discussion on the main results of the qualitative analysis and relates the findings to the quantitative studies. The article concludes with provisional findings that point out the need for further deepen key issues that help us to understand the dynamics of religious experience in modern societies.

\section{Methodology}

Morello's study team developed between 2015 and 2018 a qualitative research in the urban contexts of Cordoba (Argentina), Lima (Peru), and Montevideo (Uruguay) following the so-called "lived religiosity" approach. Their avowed objective was to find a more convincing explanation of Latin American religious vitality than the current theories of secularization or rational choice. The contributions of Nancy Ammerman (2014) guided their perspective, whose research focuses on understanding the ways in which religious experience and/or spirituality take shape in the ordinary practices of daily life.

In the case of the BAC, we replicated their research over the last three years (2016-2019), but on a more limited scale of twenty-eight interviews. Our aim was to study in a comparative perspective the lived religiosity of the Latin American population in their home countries and that of the Latin American immigrants residing in the BAC; besides, we compared the latter one with the religious experience of the indigenous population. It should be noted that we did not contrast the three populations strictly speaking, but rather the current specific ways belief relates to daily life in Latin America and the BAC, and to be more precise, the processes of pluralism, and religious autonomy.

The survey used to carry out the interviews and their codification (Atlas.ti) were the same as those used in Cordoba, Montevideo and Lima. The questionnaire had two parts, the first one referring to socio-demographic characteristics, and the second one oriented towards aspects and spaces of daily life where religious experience might take place (family, friends, work). On account of the characteristics of this survey, it was also expected that the interviewee provided other references to transcendence not foreseen by the researcher.

However, we decided not to include a second interview conducted in Latin American cities, focused on meaningful artifacts for believers. The reason for this was twofold: We had difficulties in finding people willing to carry out the interviews, and most of the interviewees answered they had no particular meaningful object.

The selection criterion for the interviewees was a purposive sample of citizens, including different age and gender groups, home country, socio-economic status ${ }^{1}$, and religious self-adscription (in our case, we confined ourselves to Catholics and Evangelicals so far). Snowball sampling was the recruitment technique; the religious diversity within our team, and the support of external researchers from our University (Deusto) were key to reach potential subjects.

Unlike our Latin American colleagues, we had difficulty finding people willing to talk about these issues, so we interview those who were willing to respond, regardless of their home country (see table below). Interviews were conducted in the place chosen by the interviewees. Although conversations were fluid and sincere, interviews were shorter than those developed in Latin America, from $45 \mathrm{~min}$ to an hour.

We are aware of the internal religious diversity of Latin America (Marzal et al. 2000, 2004; Da Costa 2003, 2008; Mallimaci 2013, 2015; Romero 2016). It is a vast continent, in which the historical and social peculiarities of the different states and communities determine the way people understand religious belief and live. However, "Latinos" are a community with strong cultural ties in the context of

1 Defining the variable "social class" was very problematic for several reasons: (a) social inequality is less acute in the BAC than in Latin America; (b) in the BAC, children moving on to higher secondary school education is mandatory, as public education is free; (c) it is not culturally polite nor appropriate asking for economic resources. Neither incomes nor educational level was helpful, so we decided to select the city's district as a social class indicator, i.e., both indigenous and Latin American interviewees lived in different cities of the BAC. 
the BAC. As a purposive sample, interviewees are not intended to offer quantitative data that describe separately migrants coming from Argentina, Uruguay, and Peru, but rather religious trends emerging in the BAC. Using the image of Rabbia (Rabbia et al. 2019), we do not try to describe the picture, but to identify its colours. Despite the pointed limitations, we do believe that the comparative approach will provide core issues to deepen the importance and meaning of religion in the lives of the interviewees.

On another level, the phenomenon of emigration has its own peculiar characteristics that make it difficult to determine to what extent the observed deviations are also influenced by individual factors, such as the characteristics of those who decide to leave their country to venture for different reasons into an unknown society.

Below (Table 1) is the list of interviewees and the corresponding identifying code, whose comments will be cited in the main body of the paper:

Table 1. List of interviewees. BAC, Basque Autonomous Community.

\begin{tabular}{ccccc}
\hline Identifier & Gender & Age & Home Country & Religious Self-Adscription \\
\hline A & Male & 32 & El Salvador & Catholic \\
B & Female & 30 & Ecuador & Catholic \\
C & Female & 41 & Bolivia & Baptist \\
D & Male & 22 & Colombia & Evangelical \\
E & Female & 53 & Peru & Catholic \\
F & Female & 22 & BAC (Spain) & Catholic \\
G & Female & 53 & BAC (Spain) & Catholic \\
H & Male & 60 & BAC (Spain) & Catholic \\
I & Female & 70 & BAC (Spain) & Catholic \\
J & Male & 53 & BAC (Spain) & Evangelical \\
L & Female & 28 & BAC (Spain) & Evangelical \\
K & Female & 32 & BAC (Spain) & Evangelical \\
M & Male & 23 & BAC (Spain) & Catholic \\
N & Female & 30 & BAC (Spain) & Catholic \\
$\tilde{N}$ & Female & 42 & Nicaragua & Evangelical \\
P & Female & 63 & BAC (Spain) & Catholic \\
Q & Male & 44 & Venezuela & Agnostic \\
R & Female & 48 & Venezuela & Catholic \\
S & Female & 24 & BAC (Spain) & Agnostic \\
T & Female & 32 & Peru & Evangelical \\
U & Male & 37 & El Salvador & Catholic \\
V & Female & 47 & Colombia & Evangelical \\
W & Female & 55 & BAC (Spain) & Catholic \\
X & Female & 54 & BAC (Spain) & Catholic \\
Y & Male & 51 & BAC (Spain) & Evangelical \\
Z & Female & 42 & Venezuela & Catholic \\
\hline & & &
\end{tabular}

\section{Quantitative Approach: The Socio-Religious Context of the Basque Autonomous Community}

Religious phenomena need be understood within a given socio-cultural context, whether in their institutional aspects or in relation to individual experiences, (Estrada 2001, p. 47; Lenoir 2012, p. 251; González-Anleo and López-Ruiz 2017, p. 241). In this regard, the fine intuition of Mardones is very significant: "[P]eople do not believe what they want, but what they can and what tradition and the socio-cultural moment let them do. Faith lives linked to representations and images that are very persistent and difficult to overcome" (Mardones 2003, p. 227). This statement does not mean that social structures nor the cultural framework shape the appearance, change or disappearance of a particular religious phenomenon, but rather that they are the plausibility structures that make it either possible or unlikely (Berger 2014). The consequences of such sociological assertion are especially important in periods of profound social and cultural transformations (Ward 2005; Bericat 2008). That is why we need to start by identifying some general features of the host society that will allow us to clarify the transformations undergone in the religious experience of the Latin American population living in the 
BAC. Then, we will briefly point out the socio-cultural characteristics, which, in our view, are most relevant in order to understand the transformation of the religious phenomenon in Basque society as a whole, as well as its current situation.

The BAC is located in the north of Spain, with a population of just over two million inhabitants. Since the early 1980s, it holds an autonomous government with broad powers in strategic areas for the economic, social and cultural development of the territory, such as education and tax collection. It is an eminently urban population, whose economy is mainly based on the secondary and tertiary sectors. Its level of social welfare is close to that of the European countries, above the standards of other Autonomous Communities of Spain. For example, in 2019: (1) Its "per capita" income is 14\% higher than the European Union average; (2) the unemployment rate is around 10\% (although it is distributed irregularly in the territory), well below the Spanish average.

The demographic factor is very significant, as it points to a series of important challenges that Basque society will have to face soon. In particular, the population is ageing: In 1981, there were 0.3 people aged 65 or over for every person under 65, while in 2016 the rate rose to 1.4, one of the highest in Europe (EUSTAT 2018, p. 12). The current growth of the population in absolute numbers is due to the migratory flow mainly from Latin America (almost half of the immigrants come from these countries), Eastern Europe and North Africa (EUSTAT 2018, p. 13), although migrants still represent a lower percentage than that of other European countries. To be precise, the flow of migrants to the BAC has increased in recent decades to represent $9.1 \%$ of the current population (EUSTAT 2018, p. 14). We should also highlight that the birth rate of these migrant populations is notably higher than that of the indigenous population (EUSTAT 2018, p. 21). In the light of these results, Basque society will foreseeably be a pole of strong migratory attraction in the near future.

However, migration is not a new phenomenon in the BAC. Until the first decades of the 20th century, many Basques became migrants, most of them to American lands. It was not until the 1960s that the trend changed and migrants from other parts of Spain arrived in the BAC. The significant influx of Spanish speakers, together with other political factors, led to a notable decrease in the knowledge and use of the Basque language, despite the efforts of civil society to keep it. Nowadays, Spanish and Basque are co-official languages, a clear example of the cultural heterogeneity of the Basque society hosting Latin American migrants. It shows its own internal challenges, such as acceptance and respect for diversity, or the capacity to generate integration, and social cohesion.

\subsection{Shifts of the Religious Phenomenon in the Basque Autonomous Community}

In the light of what has been presented so far, we can conclude that Basque society is currently characterized by a dynamic socio-cultural context that is suffered profound changes in recent decades. Amid this changing panorama, the place and meaning of religious phenomenon in Basque society are clear examples of the profound transformations undergone. In fact, one of the local religious phenomena awaiting a convincing sociological interpretation is the rapid process of secularization of the $\mathrm{BAC}^{2}$ : What in other societies took several generations, in the case of Basque society it took place in the period of barely three decades (Basterretxea 2012). In fact, during the last generations,

2 We assume P. Berger's (1969, p. 107) definition of secularization as "the process by which sectors of society and culture are removed from the domination of religious institutions and symbols". Consequently, "the modern West has produced an increasing number of individuals who look upon the world and their own lives without the benefit of religious interpretations" (Berger 1969, p. 108). This process contributes to establish a socio-cultural framework that affects daily religious experience, as highlighted by Berger (1969, p. 127): “One of the most obvious ways in which secularization has affected the man in the street is as a 'crisis of credibility' in religion (... ) Subjectively, the man in the street tends to be uncertain about religious matters. Objectively, the man in the street is confronted with a wide variety of religious and other reality-defining agencies that compete for his allegiance or at least attention, and none of which is in a position to coerce him into allegiance". We are aware of the increasing controversy over secularization theories in recent years. However, our paper is not focused on this discussion, nor whether the data provided in this paper refute any theory of secularization. In this sense, we agree with the statement of Beckford and Luckmann (1991, p. 2): "No support is given to the triumphalist scenario of secularization, according to which the declining significance of religion is a necessary feature of modernizing and modern societies". 
we passed from a strong social and cultural presence and influence of the Catholic Church (and of the concomitant Roman Catholic tradition) to a sort of social minority tending towards marginality. The data in Table 2 clearly show this change (Longo et al. 2017, p. 90):

Table 2. Religious change in the BAC (percentage).

\begin{tabular}{ccccc}
\hline & $\mathbf{1 9 9 8}$ & $\mathbf{2 0 0 8}$ & $\mathbf{2 0 1 2}$ & $\mathbf{2 0 1 6}$ \\
\hline Practicing Catholic & 14 & 8 & 4 & 4 \\
Non-practicing Catholic & 45 & 38 & 30 & 23 \\
Total Catholics & 59 & 46 & 34 & 27 \\
Unbelievers, agnostics, atheists & 31 & 43 & 54 & 58 \\
\hline
\end{tabular}

Unfortunately, no qualitative studies have been conducted so far in the BAC. It would certainly be more consistent with our methodology to describe the meaning of these profound religious changes using data and bibliography from the qualitative approach, but we lack such a study. We are aware that statistics describe a particular situation, but not necessarily its meaning.

However, it is revealing and clarifying to take into account the figures and pays attention to some features of the religious (or, rather, non-religious) profile that our society presents, since it undoubtedly affects the possible shape and future shifts of the religious experience of the migrant population:

1. Although at the end of the 1980 s $81 \%$ of the Basque population identified with the Catholic Christian tradition, the Catholic population today does not exceed one third of the total population (27\% in 2016). It has become a social minority, still significant, but it suffered a substantial decline in the short span of two decades, as Table 2 shows. On the contrary, the population that declares itself non-religious (whether atheist, agnostic, etc.) represented 58\% in 2016, which is a clear upward trend.

2. Young people mark future trends within society, and point to some possible new directions of the religious phenomenon. In view of the data of the latest youth population surveys, it can be inferred that the figure of the practicing Catholic disappears almost completely. The following table (Table 3) is very illustrative (Longo et al. 2017, p. 88): As we see in the first row, only $4 \%$ of the population between the ages of 15 and 29 defines themselves as practicing Catholics. This is a residual value, which implies that this small group is almost inapprehensible in ordinary surveys. In any case, the figure sharply contrasts with the percentage of the adult population as a whole $(18 \%)$. These figures point out in at least two directions. First, the decline in the Catholic population has not reached its minimum point of stabilization yet; the table indicates that younger generations carry an even more notable decline in Catholic membership. Second, the percentages of Catholics among young people suggest that Catholicism can lose its primacy and become a minor religion among minority religions.

3. The social reputation of the Catholic Church is very low (Urrutia 2010, p. 152; González-Anleo and López-Ruiz 2017, pp. 42-51). When people are asked about the confidence in different social institutions, the Catholic Church creates low levels of trust, and when compared to other social institutions (head of state, armed forces, NGOs, business, etc.), it ranks very low.

4. In recent decades, an incipient religious pluralism emerged (Ruiz Vieytez 2010), and many religious minorities are consolidating in Basque society. Some of them have deep historical and cultural roots in the Basque Country, despite their invisibility; on the contrary, others developed recently. In both cases, the number and diversity of religious traditions increased considerably. Each of them (including Catholicism) constitute a minority within a society that does not take a positive view of the contributions religion can make in the construction of the common good, and in the development of a more egalitarian society. In this context of religious pluralism, two types of challenges arose. With regard to the different religious traditions, these need to be placed in the secular context of pluralism, which challenges any believer (Berger 2014). As far as society 
is concerned, a large number of citizens live away from religion, and do not know its meaning (Narvaiza and Laka 2002; Pérez-Agote 2004; Sánchez de la Yncera and Fooz 2012). Religion is often linked to folklore, or outdated beliefs that have no longer part in a developed society that values scientific knowledge above all.

5. However, it is important to point out that the indigenous population continues to be tolerant of the religious and cultural diversity migration brought about (Eusko Jaurlaritza 2012). As already mentioned, society is largely unaware of the religions existing within it, but this lack of knowledge is linked to indifference, in no case to rejection or violent attitudes.

6. Finally, the contrast between the religious profile of the indigenous population and that of the immigrant population is striking. Table 4 shows the religious self-adscription of youngsters between 15 and 29 years of age, according to their place of birth (Longo et al. 2017, p. 89):

Table 3. Religious self-definition of youngsters (15-19 years old), and of adults (percentage).

\begin{tabular}{ccc}
\hline & Population Aged 15-29 & Population Older Than 18 \\
\hline Practicing Catholic & 04 & 18 \\
Non-practicing Catholic & 23 & 37 \\
Believer in another religion & 08 & 06 \\
Believer in God but not in religion & 04 & 04 \\
Indifferent, agnostic & 12 & 10 \\
Non-believer, atheist & 46 & 24 \\
No answer & 03 & - \\
TOTAL & 100 & 100 \\
\hline
\end{tabular}

Table 4. Religious self-adscription of youngsters according to the place of birth (percentage).

\begin{tabular}{ccc}
\hline & \multicolumn{2}{c}{ Place of Birth } \\
\hline & BAC & Out of Spain \\
Practicing Catholic & 03 & 12 \\
Non-practicing Catholic & 23 & 25 \\
Believer in another religion & 02 & 40 \\
Believer in God, but not in religion & 04 & 05 \\
Indifferent, agnostic & 13 & 04 \\
Non-believer, atheist & 52 & 09 \\
No answer & 03 & 04 \\
TOTAL & 100 & 100 \\
\hline
\end{tabular}

Although the number of non-practicing Catholics is similar in the case of young people born in the BAC and those born outside Spain (23\% and 25\%, respectively), the immigrant population presents low percentages of "non-religion" in its different versions. For example, $4 \%$ of "indifferent, agnostic" as opposed to $13 \%$ of the autochthonous population or, what is even more striking, only $9 \%$ of "non-believer, atheist" as opposed to $52 \%$ of those born in the BAC. In view of these results, the most discriminating factor in order to explain religious self-adscription is the place of birth. Other classic variables, such as gender, social class or educational level, seem to be less relevant when interpreting the shifts of the religious phenomenon in Basque society.

Additionally, $40 \%$ of youngsters born outside the BAC profess another religion (not Catholicism). This figure reflects an increasing religious plurality, a future scenario in which the Catholic Church will be a minority.

\subsection{The Religious Profile of Latin American Emigrants in the Basque Autonomous Community}

The Basque Immigration Observatory, Ikuspegi, offers updated data on the immigrant population in the BAC. The following table (Table 5) specifies the absolute numbers of the Latin American 
population in the BAC and their weight in relation to the immigrant population as a whole, in 2008 and 2019.

Table 5. Latin American immigration (percentage).

\begin{tabular}{ccc}
\hline & $\mathbf{2 0 0 8}$ & $\mathbf{2 0 1 9}$ \\
\hline Total of Latin American migrants in the BAC & 54,506 & 107,692 \\
Percentage of Latin American immigrant population & $47 \%$ & $49 \%$ \\
\hline
\end{tabular}

Data provided by Ikuspegi show that the Latin American immigrant population doubled in the last decade and grew two percentage points regarding the overall immigrant population.

In 2008, Ikuspegi carried out an in-depth study on the Latin American immigrant population offering a complete profile. Among many other variables, the study introduced the religious variable (Figure 1). The following are relevant to our research (Aierdi et al. 2008, p. 119):

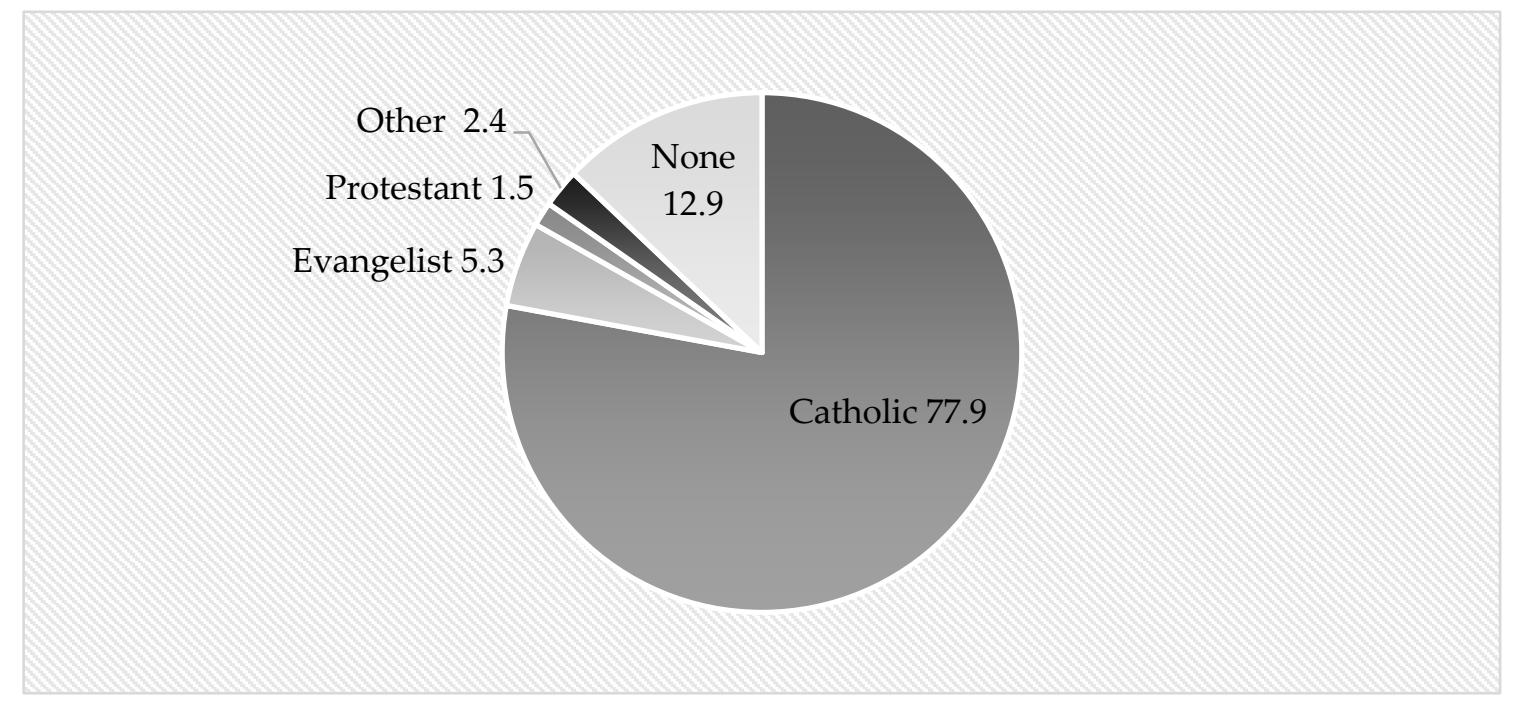

Figure 1. Religious self-adscription of Latin American immigrants (percentage).

Within Christianity, 77.9\% of Latin American migrants declare themselves as "Catholics"; $5.3 \%$ call themselves "Evangelists" (referring to Pentecostal churches) and 1.5\%, "Protestants". 2.4\% belong to other religious traditions, while $12.9 \%$ do not profess any religion. Overall, the Latin American immigrant population that declares itself as "believer" has a high level of religious practice; when asked about how often they pray, $45.6 \%$ answer they pray daily, and the figure rises to $59.9 \%$ when considering weekly prayer.

It should be noted that $79.3 \%$ of the Latin American migrant population feel that they did not have serious difficulties in continuing their religious practice once they have arrived in these lands. They answered "easy or very easy" to the question raised to the degree of easiness/difficulty they encountered in exercising their religious practice in the BAC. This very same idea is confirmed by the interviews carried out within the framework of the Lived Religion research in the BAC. By way of example, let us see what $\mathrm{D}$, one of the interviewees, says:

"I see that people here, in the Basque Country, in Spain, although they don't believe, they are respectful when it comes to what I believe, but very often people from South America who don't believe [... ] they laugh at (religion)."

Although the last group of "non-religion" is a minority (12.9\%), the study merges this figure with other variables and offers an interesting result that confirms the hypothesis of Section 3.1: That the variable showing greater explanatory ability is the home country, since $38 \%$ of Latin Americans away from religion come from Argentina. 
Regarding the variables involved in the description of the non-religious population, Ikuspegi's report sums them up as follows (Aierdi et al. 2008, p. 119):

"A good number of variables have a significant relationship with the religious self-adscription of the Latin Americans surveyed. According to gender, we perceive a higher religiosity admitted in the case of women. Age establishes a border between those under 30 years of age (younger self-adscription) and the rest of Latin American immigrants. The educational level seems to operate in such a way that more education considerably diminishes religious self-adscription. The administrative situation is also influential-it seems that stability means there is less desire to take refuge in religious beliefs. For its part, the proportion of Evangelists [sic] among those in an irregular administrative situation stands out. This higher proportion of Evangelists [sic] is due to Bolivians and Brazilians, who are in an irregular administrative situation largely than other Latin American citizens. In terms of nationalities, a large proportion of Argentines who do not belong to any religion is surprising. There is also a small relationship between residence time and religious self-adscription, with the border being established between those who have been with us for more than six years (less religious, so to speak) and those who have been with us for less time (more religious self-adscriptions). Finally, depending on the reason for emigration, those who emigrate for economic or family reasons would be more religious than those who emigrate for personal or political reasons."

The study adds one last variable to these ones: Religious institutional bonding is greater in the most economically vulnerable people, while affluent groups feel freer. Although the twenty-eight interviews conducted in our study do not provide data in this regard, it is important not to lose sight of this point for future research.

\section{Qualitative Approach. Autonomy and Religious Pluralism}

Quantitative studies, such as those outlined in Sections 3.1 and 3.2, highlight the institutional dimensions of the religious phenomenon, but they mean little or nothing for people who define themselves as "believers" and the sense of religious belief (Uriarte 2017). The Lived Religion approach, a sociological school led by authors, such as McGuire (2008) and Ammerman (2014), seeks precisely to respond to the question of meaning, the way of understanding personal beliefs and the relationships religious belief establishes with other areas of life. Ammerman argues that analysing the dynamics of religion in the daily lives of individuals does not mean failing to study religion as a social phenomenon, but rather focusing the research on non-experts.

We followed this approach to the twenty-eight in-depth interviews carried out so far with Catholics and Evangelicals (the latter calling themselves "Christians" and "Pentecostal Christians"), and gathered significant experiences that complement the quantitative data presented in the previous section. However, before presenting the interim results of the study undertaken in the BAC, we will briefly indicate some results obtained from the interviews conducted in Latin America (Morello 2017; Morello et al. 2017). We will focus only on two variables: Autonomy and religious pluralism, since both are highly crucial to explain the changes that the religious phenomenon is undergoing in contemporary societies. The transformations are such that several authors refer to them as "reconfiguration of the religious phenomenon" in the context of secularity (Mardones 1994). Both processes draw the attention of many specialists, as in the case of Berger (1969, p. 171). He concludes his classic study on the religious phenomenon in modern society with this programmatic statement:

"It is safe to predict that the future of religion everywhere will decisively shaped by the forces that have been discussed in this and the preceding chapters -secularization, pluralization, and 'subjectivization' - and by the manner in which the several religious institutions will react to these." 
Regarding the process of autonomy, individualization or subjectivization, the phenomenon has been widely analysed in recent years. For instance, Vide claimed, "in the secular city there is a lack of understanding between the persistent longings for transcendence and meaning, and the offer of salvation from religious institutions" (Vide 2013, pp. 158-59). More than three decades ago, Mardones stated: "Faced with the lack of a universal project, a Western man takes refuge in subjectivity, in the private sphere and in the individuality cult" (Mardones 1988, p. 153). For its part, Touraine (1993; Touraine and Khosrokhavar 2002) drew attention in the 1990s to the mismatch between institutional and personal dynamics, while Beck delved twenty years later into the process of individualization and its consequences for the experience of the religious phenomenon (Beck and Beck-Gernsheim 2003; Beck 2009). Duch (2015, p. 475) underlines the consequences that this process has in the classic division between "public" and "private".

British sociologist Davie $(1994,2013)$ opened the debate on the relationship between individual belief and belonging to a religious institution, and coined the well-known term "believing without belonging" to name the widespread British phenomenon of believers without institutional adscription. Her analysis led to the converse possibility, i.e., "belonging without believing" (Davie and Hervieu-Léger 1996; Day 2013; Hervieu-Léger 2016). Gauchet speaks of the end of religion, although he claims that religious experience will prevail (Gauchet and Ferry 2007). Bauman includes the process of increasing individual autonomy in his concept of "liquid society", the focus of several studies, and whose consequences in daily life are analysed in one of his last books (Bauman and Leoncini 2018). Finally, in relation to the building of social identities, several authors draw the attention to the relationship between the process of subjectivization and the spread of fundamentalist claims (Ladeur 2014).

In respect of the process of religious pluralism, attention also grew in recent decades. In the view of Pasquale and Kosmin (2013, p. 454), increasing plurality is one of the very few points of consensus reached so far by scholars:

"Amid the range of sociological positions on secularization there is an agreement on one point, even among its strongest advocates (Bruce 2002) and critics (Stark 1999): [T] he world is increasingly becoming a competitive marketplace of worldviews -religious and otherwise."

Several authors underlined the international projection of increasing plurality (Sartori 2001), as well as its specific features and consequences at the local level (Küng 2004; Skard et al. 2008), and the phenomenon also draw the attention of Basque scholars in the BAC (Ruiz Vieytez 2010; Morondo and Vieytez 2014; Rodríguez and Uriarte 2016; Elzo 2017; Uriarte and Urrutia 2018). The evolution of sociologist of religion Peter Berger is of great importance; his analysis moved from an approach centred on the process of secularisation (Berger 1969) to another one focused on the analysis of pluralism (Berger 2014).

Returning to the issue in hand, after a brief presentation of the Latin American context, we will establish possible similarities and differences between the religious experience in Latin America and that of the immigrant population in the BAC. Only then will we be able to compare the religious experience of Latin American immigrants and the indigenous population of the BAC.

\subsection{The Latin American Context}

This article presents in a comparative perspective the lived religiosity of the Latin American population in their home countries and that of the Latin American immigrants residing in the BAC, and afterwards, we will add the religious experience of the Basque population, i.e., we will identify religious features tracing similarities and differences between populations. However, an exhaustive comparison between Latin American and the Basque context goes well beyond the aim of this article, therefore, we selected two processes (Hagopian 2009; Levine 2012): (1) The increasing moral autonomy of the individual, set up as authority himself; and (2) religious pluralism in a double aspect: The one that arises within each religious tradition, and the one that characterizes contemporary society. 
Therefore, our priority is to establish the starting point that will serve as a reference point and as an element of contrast in the subsequent comparison. Next, we offer the provisional conclusions of the research team led by Morello (Rabbia et al. 2019), which will allow us to establish similarities and differences in the religious experience of the Latin American population that migrated to the BAC. The qualitative approach of Morello's study ("lived religiosity") offers a deeper and more nuanced knowledge of the transformations that affect the religious experience of those interviewed in Argentina, Peru and Uruguay.

Regarding the first process (the increasing moral autonomy of the subject), the authors prefer to use the term "autonomy" instead of "independence", because surveys confirm that the Community dimension, i.e., the link between the individual and the institution still persists. The relationship established by the subject with his or her reference group is significant, even though that community is neither the official institution nor the hierarchy. In other words, although the religious panorama in Latin America is less institutionalized, it is not "individualized".

With respect to the second process (pluralism), the researches claim that the greatest religious transformation in Latin America is due to the challenge raised by Pentecostals and disaffiliates to the hegemony of the Catholic Church. To this process should be added the internal pluralization of Catholicism, a pluralization that, paradoxically, Catholicism always promoted.

\subsection{Comparison between Latin American Populations}

Down below, we present the similarities and differences of the religious experience of Latin American people residing in Latin America, on the one hand, and of immigrants in the BAC, on the other. We finish this point with Table 6 summarizing the results.

Table 6. Summary. Comparison between the Latin American population of Argentina, Peru, Uruguay, and the immigrant population of the BAC.

\begin{tabular}{|c|c|c|}
\hline & Similarities & Differences \\
\hline Autonomy & $\begin{array}{l}\text { Both populations distance themselves from } \\
\text { the respective ecclesial institutions. } \\
\text { In both groups, there are discrepancies with } \\
\text { religious leaders. } \\
\text { Both populations distance themselves from } \\
\text { official moral standards, especially on } \\
\text { bioethical issues. } \\
\text { In both groups, personal experience } \\
\text { occupies a central place in the process } \\
\text { of reflection. }\end{array}$ & $\begin{array}{l}\text { - Among the immigrants residing in the } \\
\text { BAC there is no "religious hybridation" } \\
\text { in the self-adscription. } \\
\text { Immigrants residing in the BAC do not } \\
\text { manifest "religious hybridation" in } \\
\text { the practices. } \\
\text { - The use of images or objects is noticeably } \\
\text { lower in the immigrant population. } \\
\text { Among Latin American immigrants in } \\
\text { the BAC religious experience } \\
\text { is privatized. }\end{array}$ \\
\hline Pluralism & $\begin{array}{l}\text { Both populations have a clear awareness of } \\
\text { the multiple religious options available } \\
\text { to them. } \\
\text { Both groups show a fluid acceptance and } \\
\text { experience of religious pluralism. } \\
\text { Both populations appreciate mutual respect } \\
\text { as a necessary value for coexistence. } \\
\text { Both collectives show signs of "cognitive } \\
\text { contamination" or crossbreeding of beliefs } \\
\text { in their images of God. }\end{array}$ & $\begin{array}{l}\text { - Immigrants residing in the BAC do not } \\
\text { individually seek knowledge of } \\
\text { other religions. } \\
\text { There is an ambiguous assessment and } \\
\text { different levels of acceptance of religious } \\
\text { pluralism among the immigrants in } \\
\text { the BAC. } \\
\text { Among immigrants, the limits required } \\
\text { for the coexistence between different } \\
\text { are indefinite. }\end{array}$ \\
\hline
\end{tabular}

\subsubsection{Autonomy}

Interviewees related their experiences without explicitly mentioning theoretical concepts, such as "autonomy" or "diversity"; however, from their narrations, we can infer what Morello's study calls "markers of autonomy", or in Rabbia's words, "buts" (Rabbia et al. 2019). Individuals use adverse conjunctions of the type "but...", "although ..." to express with different degrees of intensity their disagreement, distancing or differentiation with respect to the following questions. 
Disagreements with Religious Leaders

As can be seen in Latin America, the positions of Latin American immigrants on bioethical issues, such as the use of condoms, homosexuality, abortion or euthanasia differ greatly from the postulates defended by the ecclesiastical hierarchy. This discrepancy is notorious in all the Latin American Catholics interviewed, and even among "Baptists" and "Evangelicals" although, in those cases, cautiously.

A responds to the interviewer that

“ ... the Church in general, especially the Catholic Church, has many outstanding debts. The issue of abortion, of women's rights, of being able to decide on their bodies, the issue of the use of condoms ... The Church still has a position that seems to me to be very old-fashioned, come on, from the 15th century!"

$\mathrm{Z}$ tells us that his mother, a fervent Catholic and until a few years ago practicing

“... I don't know, I think he learned to see priests more from the human point of view. Furthermore, I believe that she was also very affected when she opted for contraceptive methods and was told that she was almost excommunicated!"

$\tilde{\mathrm{N}}$ tells us that he lived

“... I believe that God has not commanded us, for example, to submit ourselves to the yoke of another person's slavery, and it is from that point of view that I took the initiative to separate myself, because God says in his word that he called us to freedom."

T tells that he knew of a girl who

" ... everyone has pointed the finger at her, including my church, and in the end I found out that the girl decided to have it, but it was a rape [ . . ] In that situation I think: 'What if I had been raped in that assault?' I would have aborted. I tell you so. I know that in my religion this is not well seen, but $\mathrm{I}$, in my situation, in my humble opinion, as a human being respect it."

The first two quotations are from Catholics, the last two from Evangelicals. All four express a moral autonomy that is the result of a process of reflection, in which the experience has ended up valuing their particular beliefs. They manifest personal experiences that we could consider inflection points, circumstances that made them reconsider and redefine, not without effort, their individual positions, the way to integrate their beliefs in life and the commitment that those entail. To the statements collected in the previous paragraphs we could add others in which, like V, people state "for me the priority is always people as human beings [ ... ] no matter if it is in our community or in another religion, love for the person is above religion or whatever it is".

\section{Religious Self-Identification}

In contrast to the results obtained in Latin America, none of the interviewees expressed themselves in a different way from "Catholic", "Evangelical" or "Protestant". Neither Catholics nor Evangelicals use mixed sui generis categories as those cited in Morello's study, which, for example, combine "Catholic" and "agnostic" for self-identification (Rabbia et al. 2019). However, it should be noted that the adverse sentences referring to questions of religious self-adscription are found, in Latin America, only among Catholics and appear recurrently.

B comments that

"I'm Catholic, I believe in God, in the Virgin too. But to practice praying and such not, or to have a Virgin at home, neither. I'm not one to go to Mass either, but every now and then I do. All I do is to teach my children that they have to cross themselves at night before going to bed." 
A explains, "The Catholic instruction from my mother was that you should help the person, not go to church, not to mass. [ ... ] I don't have a prayer that safeguards me, that kind of thing, no." For his part, R affirms that "I still believe in God, but I don't practice [ . . ] I can go to church; in fact, when we go on a trip we visit cathedrals, but pray, go to Mass, to funerals, no".

The Evangelicals interviewed also point out their autonomy with regard to the norms, as in the case of $\mathrm{V}$, but it is important to note that the freedom expressed is due to the fact that Evangelical religious life values obedience to the Bible above human norms (understand "conventions"):

"Norms do not govern me, because God has given me complete freedom. I am a free person; what I do I do is guided by the Bible, because the word of God is above the shepherd, I do not serve men."

\section{Religious Practices}

The practices manifested by all those interviewed responds to what we might consider "conventional" religious practices, although we need distinguish two types: On the one hand, practices linked to community worship and personal devotion (prayer, attendance at celebrations, spiritual exercises, reading the Bible) (Coupeau 2017); on the other, those related to social commitment towards the most disadvantaged people. Among Catholics, stand out these latter and practices that we could consider "domestic"; for example, B teaches her children to cross themselves before going to sleep (see above); $R$, although she is far from any institutional practice, states that every day she calls her children by telephone to give them her blessing. For their part, Evangelicals practice prayer in the domestic sphere, as well as participation in the worship of their church and in social projection activities.

In this aspect, there are notable differences between Latin American immigrant believers and those living in Argentina, Peru and Uruguay. Firstly, Latin Americans living in the BAC do not mention mixed practices or practices from other religious traditions. For example, no person interviewed talks about tattoos or yoga (which is found in Morello's study), nor is there any mention of the religious use of social networks.

Secondly, the Latin Americans of the BAC do not "expand" religion outside the religious context either, leading to privatization of beliefs and practices. That is to say, habitual practices in Latin America, such as sharing their beliefs with co-workers, are not carried out in our case, something that some interviewees seem to miss.

\subsubsection{The Experience of Religious Pluralism}

In the interviews conducted in Latin America, the experiences linked to religious pluralism are organized into three groups, namely: (1) Those who seek individually and for various reasons to contact with and to know other religions; (2) those who have the experience of diversity through members of the extended family, friends or acquaintances; and (3) those who within the nuclear family coexist with people of other faiths (Romero 2019).

It seems to us an aspect worth noting that in none of the interviews given by Latin Americans residing in the BAC are there any records of individual experiences of a diversity intentionally sought after (the first group of the analysis carried out in Latin America). Recorded testimonies are only from interviewees willing to share their reflections and experiences with people of other faiths, but always from their own religious tradition. On the other hand, we do find numerous examples of the following two groups.

Next, we will divide our analysis between the testimonies of the experience of religious pluralism in the wide circle of social relations (coinciding with group 2 of Morello's research) and those that refer to religious pluralism within the family up to the generation of grandparents (equivalent to group 3).

Given the importance acquired from the analysis of the interviews, we will close the section by adding a point dedicated to "religious hybridation", exemplified in the images of God. 
Out of our presentation, however, are aspects that we could attribute to contact with a receiving society other than one's own. For example, the fact that several women interviewed in the BAC value positively living in a less macho society, or the lesser willingness of some to share their faith in the Basque host society.

\section{Pluralism Lived in a Secularized Society}

$\mathrm{R}$, a Catholic, is a clear example of the positive experience of religious pluralism in her circle of friends; it already allows her to see things differently, to value the person and to highlight the necessary respect for individual freedom in the face of what she defines in another moment of the interview as "the market of religions":

"In my group of friends, I have a Muslim friend, who is a very close friend [ ... ] My first marriage, the boy I married was a Christian Maronite. Later, Jewish friends, but all of them converged in a single thought with something that was divine, that each one called it in a different way. That's when I tell you not only is this, but there is another vision of the world, there are other ways of seeing life and that's when I say 'iya va!', it's not just this truth they're telling me."

From the point of view of the social management of diversity, $\mathrm{R}$ understands that the State needs to be secular, respect any belief and allow people to develop their personal choice. At the same time, he understands that those who emigrate need be willing to relax their approaches and adapt to the host society, since "you can't think that society adapts to you, because I think it's absurd".

A similar position is that of A, a Catholic, who comments on the following:

"I like having friends from different religions because I learn, I ask and, above all, I learn a lot [ ... ] I like non-believers when they have solid arguments as to why they don't believe and don't attack the believer, so to speak."

A appreciates the importance of gestures of rapprochement between leaders of different religions, because he understands that in this way positions are brought closer together, and an important message is transmitted: "[W]e are not against the opposite religion, but we respect beliefs, we respect principles [ ... ] I think these interreligious approaches are very good".

Although with different nuances, due to the intensity of the belief "strong" in Evangelicals and "morbid" in Catholics, to use the expression of Vattimo (2010, pp. 68-69), among Evangelicals we also find a positive evaluation of religious pluralism.

V, Evangelical, relates her encounters with people of other religions. Although he confesses that he only knows the God of the Bible, he tells us that

"we ended up with some Muslim people and we were at his house eating. I'm telling you, to me the person is first; the rest, religion, race, colour, I don't care. We had a great time with them, we knew a lot about their culture, their lives. We see the girls in the street and we love them."

For her part, $\tilde{N}$, an Evangelical, says that she has Catholic friends with whom she talks "especially about spiritual matters, about social issues, for example, how society here sees things and how we see it there [ ... ] we have a very beautiful friendship". She also has Muslim friends with whom she enjoys talking "about what their religion is like, what their god is like, what Allah is like, I love talking to them [ ... ] When they celebrate Ramadan, for example, I have been invited to eat".

When one of her children tells her about the problem of having to celebrate a saint's day when they (the Evangelicals) don't, N comments:

"And then I said to him: 'Love, if that person is already in the presence of God and was a good person, you have to respect nothing else, [ ... ] that person believed in God, the school where you go is a school that has faith in God and their God is the very God of us'." 
In the cited testimonies of Catholics and Evangelicals, we appreciate differentiated positions in the face of religious pluralism: We can describe the first as that of people who "learn" from/with diversity; the second is that of those who only "live" with it. However, both positions share two attitudes: An acceptance of diversity that is not especially problematic and the need to show respect between different people. In several cases, establishing the limits to the behaviour of each of the parties is perceived as a task that is not always easy.

We read B, Catholic:

“We get along very well. [ ... ] Evangelicals like to talk a lot [about their faith], but I say: That's it. [ ... ] I'm clear, I'm Catholic and I don't change there. If you want to explain to me, that's fine, I'll listen to you, but that's as far as it goes."

T, Evangelical, underlines that:

"When we go out with non-Christian friends, we accommodate to them. Sometimes we say, 'Should we give thanks for food?' If they say 'yes,' we pray, and if they say 'no,' we do not pray. [ ... ] If the moment is adequate, then we give our point of view; otherwise, we do not."

The preceding testimonies allow us to identify two elements common to the Latin American populations of Argentina, Peru and Uruguay, and the BAC:

1. The acceptance of diversity, together with a "fluid" experience of it, to use Romero's term, which consists of an attitude of rapprochement and dialogue with people of other faiths (Rabbia et al. 2019, p. 89). However, in the interviews carried out among the Latin American immigrant population, the existence of different levels of acceptance and different attitudes towards it is confirmed, which would merit a more profound analysis.

2. The conviction that mutual respect is necessary for coexistence, as well as imposing certain limits on behavior in society. In the case of the BAC, the interviewees are aware of the possibility of discrepancy and confrontation, even between believers of the same religious denomination, as well as of the necessity of limits, but those limits appear quite indefinite, and the red lines, which, in the opinion of the interviewees, should not be exceeded, are not clear. Although respect is the most frequently mentioned requirement, it seems to be accompanied by a subjective assessment that would establish the rules of the relationship case-by-case.

To conclude, it seems important to us to point out that in the interviews both, the state and the religious institutions are asked to contribute to the establishment of a relational playing field that allows free religious choice, avoiding prejudices and stereotypes.

Pluralism Lived within the Family

Since many of the interviewees have partners of other faiths, references to the ways religious diversity is managed are abundant. We find two main positions: One comes from those who understand that if there is respect does not have to be problems, and the second one comes from those who consider that the union with a person of different beliefs is always problematic.

$\mathrm{Z}$, is a Catholic, married to an agnostic who is son of a Catholic mother. Z's mother and grandmother are Catholic; the father is "more atheistic", just like the maternal grandfather who "had no religion either, was more trade unionist, almost communist", while the paternal grandfather was Sephardic and "practiced the Kabbalah". Z's mother always respected the Judeo-Christian symbolism, and the father respected the mother's Catholic belief. Speaking of how this family situation influences in the relationship with her husband, $\mathrm{Z}$ tells us that

“We have problems, but not at a religious level, more at a political level. [ ... ] If you have very contrary beliefs, perhaps in these areas there will be a conflict, even if you can negotiate later." 
If $\mathrm{Z}$ represents the example of someone who, although recognizing the difficulties, defends the possibility of a peaceful negotiated coexistence, the experience of $U$, also Catholic, is, on the contrary, negative:

"The advice I would give to any person is: [N]ever marry a person of different religious ideology, it may be that they come to reconcile it, but it is very difficult, especially when the other person is more devoted to the religious issue. [ ... ] In my case it has been difficult, very difficult."

U talks about what he considers an exaggerated religiosity that leads his wife to judge everything as being sin, and that has even caused her problems that have required psychiatric treatment. U shows his concern in the interview, because he does not want his daughter to socialize in an understanding of God and religion that could lead her to situations similar to those of his mother.

$\mathrm{Z}$ does not have children, but if she did, she would like to educate them in the Catholic religion. The commitment to transmitting one's faith is an important aspect for all believers, Catholics and Evangelicals, and at the same time, one of the reasons for the couple's problems. Moreover, unanimously, all affirm the necessary respect for the religious choice they children could make. This will obviously not prevent pain, frustration or resignation if they make a choice other than the one in which they were brought up. The following testimonies serve as a sample:

R: "I think it's important for children to be able to decide. B: "In other words, of the religion that I am or of another, whatever they want, I do teach them what I have been taught [ ... ] I would like them to believe." V: "My daughter is now 23 years old and since she was 18 she has moved away (from religion) [ ... ] but that's not why I'm going to take her to church on a forced basis [... ] We do not own anyone's life, even our children, there comes a moment when, I repeat, they are going to make their own decisions."

To conclude this point, A introduces another aspect that we find interesting, such as the place that religion occupies in the hierarchy of interests of the couple:

"My current partner is of a different-similar confession [ ... ] she declares herself to be of that religious confession (Christian orthodox) but not a practitioner of that religious confession [... ] at this moment we do not have difficulties because of religious issues, because it is not in the priority."

A's words situate us in front of the people's need to constantly prioritize and redefine the challenges that daily life imposes. A and her partner, both believers, are more concerned about what they call "the cultural question" than about choosing the religion to educate their children, who will have to learn the language and culture of their father, that of their mother and that of the host society, to which they will certainly have to add the learning of English. In this context, perceived as extremely complex, the religious question becomes secondary.

The Images of God as an Example of "Religious Hybridization"

In Berger's terms, we would speak of "cognitive contamination" (Berger 2014), which consists of reinterpreting or reformulating central concepts of one's own religious tradition based on the presence of other religious traditions and their respective visions.

In this last point, we, again, find similarities between the Latin American populations on both sides of the ocean. Along with the traditional Christian conceptions of an omnipotent, omniscient, omnipresent, provident, prayer-answering God, we find numerous references to a God understood as "force" or "energy", both among Catholics and Evangelicals, which, we consider as a clear sign of "religious hybridization".

N comments that 
"My life is completely marked by the presence of a divine being, which is that force that moves and transforms everything in the universe. Scientifically they can call it dark matter; the ancients called it arjé, in many ways. Today they call it the inner self."

In R's testimony, God is troubled, but even in the midst of doubt, he helps in difficult moments, if only for each one to give his/her own answers:

“... could be like a divine force that gives you comfort, that gives you tranquillity, to whom you can talk... But, of course, it's like a reflection where I produce my own answers, because there's no one to answer you, right? [ ... It's] like a monologue, but in connection, and I'm talking to God."

Z goes to Mass regularly, does spiritual exercises, is a Caritas volunteer, wears the medal of Saint Ignatius with the cross and the Star of David. Even a person as committed as she says the following:

“Benedetti has a phrase that I like very much, 'I don't know if God exists or not, but I don't think my doubt offends him either'. In those [difficult] situations I am empathic with that phrase [... ] I don't know if it exists, or not, but it helps to reassure me, to stay calm and to know that things are going to go well. Basically, that is my relationship with Him."

For A, "the God is that, [ ... ] the person next to me, and not the divine God whom I should venerate and respect. I continue to learn from others, I continue to read, I continue to question my own convictions..."

All these testimonies clearly point towards the autonomy of individuals, exemplified in the images of divinity that appear in the interviews carried out.

\subsection{Comparison between the Latin American Population Living in the BAC and the Indigenous Population}

Finally, we focus on the comparison between the Latin American immigrant population living in the BAC, and the population born in the BAC. Following the criteria established in the presentation of Section 4, the content of the comparison focuses on the processes of autonomy and religious pluralization. We finish this point with Table 7 summarizing the results.

Table 7. Summary. Comparison between the Latin American immigrant population and the indigenous population of the BAC.

\begin{tabular}{lll}
\hline & \multicolumn{1}{c}{ Similarities } & \multicolumn{1}{c}{ Differences } \\
\hline Autonomy & $\begin{array}{l}\text { Both populations distance themselves } \\
\text { from the respective ecclesial institutions. } \\
\text { In both groups, there are discrepancies } \\
\text { with religious leaders. } \\
\text { Both populations distance themselves } \\
\text { from official moral standards, especially } \\
\text { on bioethical issues. }\end{array}$ & $\begin{array}{l}\text { The Evangelical immigrant population } \\
\text { living in the BAC shows a greater desire } \\
\text { for ecclesial attachment. } \\
\text { The immigrant population re-elaborates } \\
\text { the use of images or objects. }\end{array}$ \\
\hline $\begin{array}{l}\text { Both collectives show signs of "cognitive } \\
\text { contamination" or hybridization of } \\
\text { beliefs in their images of God. }\end{array}$ & $\begin{array}{l}\text { Pluralism is not explicitly manifested in } \\
\text { the autochthonous population of the }\end{array}$ \\
& $\begin{array}{l}\text { Basque Autonomous Community. } \\
\text { The autochthonous population relates } \\
\text { pluralism with intra-ecclesial reality. } \\
\text { There is an ambiguous assessment and } \\
\text { different levels of acceptance of religious } \\
\text { pluralism among the immigrants of the } \\
\text { Basque Autonomous Community, } \\
\text { considered in some cases as a } \\
\text { conflictive factor. }\end{array}$ \\
\hline
\end{tabular}


However, before going on to present the possible similarities and differences between the two populations, it is important to recognise the limitations of the research carried out so far, due both to the number of interviews carried out (only twenty-eight) and to the conditions inherent in the qualitative approach. The discussion that we offer of the obtained data, far from pretending to make convincing assertions, seeks to provoke hypotheses that guide future research.

\subsubsection{Autonomy}

The interviews reading indicates that both, the Latin American immigrant believing population and the indigenous believing population, are distant from their respective ecclesial institutions, as we saw in the discrepancies with the religious leaders in the previous section, dedicated to the comparison of Latin American populations on both sides of the Atlantic.

The distance from the ecclesial institution is underlined on several occasions, implying that people feel to some extent free (i.e., autonomous) to elaborate their faith. The following quotation from $\mathrm{F}$ is a clear example of this:

“No, I don't follow religion to the letter for anything. I think everyone has its faith, that is, there is no faith for everyone. [ ... ] for me, my faith can be the kids I'm in groups with, or the group I'm in, or the things we're dealing with, that can be faith for me, it doesn't have to be believing in God and in He talking to you."

This young woman, who declares herself as a Catholic believer, underlines the distance that separates her from religion (we could translate: From the official version of the institution); moreover, she perceives that it is not a unique case, since each one can make his own version: "[T]here is not one faith for everyone". She then explains the content of her faith, which for her is very significant, and concludes with a striking expression: "[T]hat doesn't have to be believing in God". Her words might be a good example of what several authors have labeled "religion à la carte" (Mardones 1994; Schlegel 1995).

The issues of personal morality constitute a first area in which processes of personal autonomy with respect to the institutional frameworks of religious traditions are clearly stated, especially around bioethical questions. We recover part of T's testimony, quoted in previous pages:

"But now, as a mother, I see her with empathy [ . . ] In that situation I think: 'What if I had been raped in that assault?' I would have had an abortion. I tell you so. To my freedom, I tell you, despite my Christian principles."

This Latin American Evangelical woman is very clear about what her church says about abortion. However, based on the vital experience of a violent assault when she was young, she elaborates her own moral criterion that leads her to move away from the ecclesial norm, asserting that she feels free to disagree on such a sensitive issue as abortion. This same kind of personal freedom applied to moral issues is also underlined in a person of the BAC belonging to the Catholic Church. $\mathrm{N}$ affirms the following: "I believe that they are very categorical in certain things, and that there are certain values or principles that even pass over people; and no, I do not share that".

A second area that indicates the distance from the institutionalized practice is the religious celebration, which seeks to develop and share closer, more personal experiences, as we read in the following excerpt from the interview offered by $\mathrm{M}$ :

"I am currently in charge of faith in the group [scout] [ ... ] a space in the group for it to be celebrative and to show that the group is not something different from religion, because what we want is post-communion groups, to continue maturing that faith."

Although it is clear the trend towards autonomy among the Latin American immigrant population, as well as among the indigenous population, we can identify traits that mark slight differences between the two groups. 
Various testimonies of the immigrant population express a desire for greater ecclesial bonding, something that we do not find in the autochthonous population. The following comment by $\mathrm{C}$ is very revealing in this respect:

"The truth is, I would like to get much more involved in the church, because in Bolivia I was used to being in more activities organized by the church; the same when I was in Geneva, because the brothers met more, there was more coexistence. On the other hand, here I feel that they all go on Sundays and then everyone goes home, that is what I see is missing here."

The reasons for this desire for greater involvement can be very diverse; in any case, the ecclesial experience that it transmits presupposes the existence of previous very close community relationships and with a high degree of ecclesial commitment that is lacking in its experience in Bilbao.

Finally, some Latin American testimonies show a peculiar use of images and traditions that imply a reworking of their own spiritual experience. We read the quotation from E: "[I do not pray] I have my way of understanding my belief [ ... ] I usually make the sign of the cross [ ... ] I have on my bedside table photos of Father Urraca and the Lord of Miracles". This practice is not found in any of the interviews conducted with the indigenous population.

\subsubsection{The Experience of Religious Pluralism}

\subsubsection{The Different Perceptions of Religious Pluralism}

A difference that powerfully calls attention to the perception and experience of religious pluralism is that this issue arises in several interviews conducted with people from Latin America who currently reside in the BAC, but does not appear in the conversations held with the indigenous population. This fact does not mean that the autochthonous population does not have any created opinion on the pluralization of the religious phenomenon, as demonstrated by the studies carried out in the territory (Eusko Jaurlaritza 2012). Thus, the fact that the question does not arise spontaneously in the conversations leads us to conclude, in the absence of a more in-depth study, that religious pluralism does not generate interest, perhaps because it is not problematic at the moment.

On the contrary, in interviews with the indigenous population, the experience of religious pluralism is related mainly to the intra-ecclesial environment. For example, Y, Evangelical, affirms, "you know, then within the same religions there are their little groups and their discrepancies as well". In this same line is the following testimony of $\mathrm{N}$, Catholic:

"I believe that within the Church there is everything, each one interprets a value as he pleases.

The value of the family for me is one thing and for other people it is another; there are manifestations [for the defense of life and the family] in which I would never leave."

The religious minorities coming from the BAC probably sustain this perception of intra-ecclesial religious pluralism. The greatest differences are found between the native Catholic population and the immigrant population, as we can see in the dialogues held with the Latin American population.

In the following, we analyze three different cases. A first interviewee expresses a factual situation. He describes the diversity of religious faiths in his family:

"[My family] are all Catholics. Well, my father's family, siblings and that, then I have a family of uncles and that, which are in other religions that is, not Catholic, not the whole family we are exactly in the same religion. [ ... ] There are Jehovah's Witnesses and Evangelicals, my grandfather, for example."

On the one hand, B wishes to emphasize the bonding and unity of his family around the Catholic tradition: "[E]veryone is Catholic". However, immediately, he describes a plural reality of the extended family, linked to various faiths and religious traditions. Finally, he exposes the case of the grandfather, with which the reference to the experience of pluralism in religious belonging returns to the circle of 
the nearest family. In any case, the tone of the intervention is descriptive: Ot is a characteristic of his family reality, lacking any kind of evaluation.

The second example shows the existence of this religious pluralism, but on this occasion, $C$ introduces a malaise:

"I don't know, but then in the same Pentecostals some speak of apostles, others say no. That is what I don't like [... ] that there always comes a time when as humans we put our criteria, our doctrine, whether Catholics or Evangelicals."

The reference to religious pluralism is situated within Christianity, unlike the previous case that mentioned other non-Christian traditions. Three groups are alluded to, Pentecostals, Catholics and Evangelicals. There is an affirmation that marks the whole of the reality that is described: "[T]hat's what I don't like". First, it alludes to some kind of doctrinal discussion on the subject of apostolicity, in which he notes that there is no agreement. Later, he expresses a criticism, apparently directed to all Christian confessions, because there is a general tendency to impose strictly human criteria, with which $\mathrm{C}$ associates religious pluralism to, in his opinion, this pernicious tendency: "[A]lways as humans we put our criteria, our doctrine". Be that as it may, far from understanding pluralization as richness, her experience of it causes her uneasiness and a certain unease. There are no positive aspects to highlight, and it is only an obstacle to overcome.

In our last testimony, $\mathrm{D}$, beside the description of increasing pluralism expresses a negative value judgment that probably also underlies the case mentioned above:

"My friends can believe in God as I believe, many are not practitioners, many do not agree with some things, many do not agree with other things, many have been, have strayed, have gone. Yes, I believe that although we believe in the same thing, we are all different."

The testimony begins by affirming a meeting point ("my friends may believe in God as I believe") but continues recording the disagreements. D does not make explicit the content of the disagreements, but includes a reference to the abandonment of the group: "[M]any have been". Apparently, some of his friends are now in another group, which leads to a negative judgment: "[T] hey have strayed". Finally, he takes up again the initial affirmation of sharing the same creed, but he underlines the difference, on which lies the criticism of doctrinal deviation.

In synthesis, we can affirm in relation to the process of religious pluralization that it does not take part in the topics of conversation of the autochthonous population, but it certainly appears among the discourse of the Latin American one. If we attend to the different testimonies shown in this part (as well as in the previous one), we need to remark that the consideration provoked by the pluralization of the religious phenomenon is, to say the least, ambiguous. For some Latin Americans, this is interesting and enriching; but for others it is a source of discomfort and uneasiness.

\subsubsection{The Images of God as an Example of "Religious Hybridization"}

As we saw in Section 4.2.2, one of the indicators of religious pluralism is the "hybridization" of beliefs that characterizes the different images of divinity. This hybridization, closely related to autonomy, also points out the individual itinerary undertaken by those who, even though they consider themselves undoubtedly believers and practitioners, separate themselves from the orthodox images that characterize the official ecclesial formulations.

In this regard, we find an evident point of convergence in the testimonies of both populations. Let us see, by way of example, some expressions and descriptions of what is understood by "God" (Basterretxea et al. 2019):

X: "I believe that, if I have to define God as one feels him [ ... ] it is like the presence of life, it is to empty the mind and leave space for nothingness. We do not see God like this, apparently, and we never consider that nothingness is what harbours everything in life." 
P: "I think it's an energy, I don't think it's flesh and blood, that is, it's an energy and it's in us, it's that golden part, that spiritual part in us. That's God."

S: "Everything comes from a beginning and everything is connected in some way [ ... ] My God would be like mother nature or something like that, not a god as such, as a god is understood."

Q: "I feel that there may be something greater than us, that can be called the mystery of life or whatever, but personally, I find it hard to label it as a religion."

R: "I'm a mathematician, and then they say to me, 'How can anyone in the mathematical area believe that there is something that they haven't seen, that they can't prove?' I say, 'Well, I don't know, because I can feel it in the sense of the miracle of life'."

The first three testimonies $(X, P, S)$ are from people born in the CAV; the last two $(Q, R)$ are from Latin-Americans. In none of them appears a doctrinal expression about God, and even among the testimonies that come from the Christian tradition $(X, P, R)$ there are evident differences in the very conception of the divine reality. Moreover, without further qualification, all of them are considerably far from the Christian dogmatic formulations. In the testimony of $X$ the influence of the wise religious traditions coming from the East is intuited; she goes on to say: "I believe that sometimes you have to leave room for nothing, not to think anything, not to define anything".

In most cases, the term "God" is linked to some kind of personal experience: Both those who declare themselves Christians and those who define themselves as agnostics express some reference to divinity in the key of experience. Thus, the terms "energy", "mystery" or "nature" are used without a descriptive value, and yet with an evident and profound symbolic character. This fact obliges us to rethink the theory around the binomial usually used in surveys and in sociological reports "believer-non-believer", which until now has been given a strictly religious meaning.

\section{Discussion}

In the current context, the religious phenomenon is subject to new social and cultural conditions that are likely to provoke significant changes (Taylor 2015). Nevertheless, those changes run the risk of being unnoticed in the context of a deeply secularized society, where the religious phenomenon may be present but not visible. The qualitative approach towards religious phenomena demonstrates to have several advantages, even without losing the limitations pointed out throughout the article. First, it brings out processes that cannot be measured by quantitative methods (McGuire 2008; Ammerman 2014); second, it alerts us to the changes taking place within societies and religions; finally, it makes possible to develop new hypotheses on the reconfiguration of the religious phenomenon based on the study of religious minorities.

Our analysis is focused on the processes of pluralism, and religious autonomy developed among believers from the Latin American population, both in America and in the community living in the $\mathrm{BAC}$, as well as from the indigenous population. When comparing the features of the Latin American population in its home country and in the BAC, we identify very few asymmetries; e.g., the absence of the so-called "religious hybridization" referring to practices and self-adscription among the immigrant population. Otherwise, there is a continuity of experiences and stances on both sides of the Atlantic.

First, this leads us to think that we find ourselves facing global processes on both sides of the Atlantic (Morello et al. 2017), second, that secularization is linked to a certain type of society. Accordingly, future transformations of the different socio-cultural traditions that interact in relatively small geographical spaces are not clear (McGuire 2008), as is the case of the BAC (Ruiz Vieytez 2010; Morondo and Vieytez 2014). In this respect, one of the most interesting issues for future research is the study of the perceptions and reactions of the highly secularized autochthonous population to the new presence of religion; as far as collective thinking is concerned, religion is a heritage of the past 
that has nearly disappeared. Correspondingly, it might be interesting to analyze the influence of the secularized context on religious minorities.

The in-depth interviews carried out in Argentina, Peru, Uruguay and the BAC reflect a complex and nuanced reality, where religious pluralism and the increased autonomy of beliefs blur some of the boundaries that quantitative categorization had established in a restrictive way. Seen from Lived Religion studies (Rabbia et al. 2019; McGuire 2008; Ammerman 2014), issues, such as religious belonging, its content and meaning, as well as its experience, challenge the traditional sociological divisions between "believer"-"non-believer", or "religious"-"secular". There might be place here to reflect upon what Chaves calls the "religious congruence fallacy" (Chaves 2010).

The Latin American population, whether in their home countries or the migrants living in the BAC, whether Catholic or Evangelical, is aware of the reality what Berger (2014) has referred to as "plurality" and "religious pluralism". The interviewees give examples of pluralism in the family and in wider social relations as well. In clear contrast, the autochthonous population is less aware of religious pluralism. Moreover, Catholics are barely aware; they do perceive; however, an intra-ecclesial pluralism.

On the whole, the social impact of religious pluralism is valuated in terms of opportunity and enhancement in the case of broader social relations. However, that does not apply to family relations, which are closer and more significant. The interviewees voiced concern: Religious diversity is a stress factor, probably due to more intense "processes of cognitive contamination" (Berger 2014, p. 2), which cause a high degree of unpredictability and are a greater challenge for any religious tradition (Berger 2014, p. 15).

Interviews show that religious experience is significant for the immigrant population. However, an adaptation to the socio-cultural context seems to take place: Religion has a more or less noticeable public presence in Latin America, while Latin Americans living in the BAC live their religious experience more privately, without seeking or wishing an increasing role of religious experience in public life (work, politics, etc.).

While recognizing the potential difficulties of coexistence, it is noteworthy that respectful and tolerant attitudes towards religious diversity are largely the majority in the context of pluralism. This statement is consistent with the surveys conducted on this subject in the BAC (Eusko Jaurlaritza 2012). It is equally significant that none of the interviewees reveals any tendency towards fundamentalist positions, without renouncing their intense religious experience.

All the populations studied shared a common trait, i.e., the erosion of religious institutions, even though there were some nuances between the Catholic community and the Protestant community. Several scholars raise this phenomenon (Davie 1994; Beck 2009; Bauman and Leoncini 2018), which is a clear symptom of the ongoing autonomy of believers regarding the guidelines of their corresponding ecclesiastical authorities (Beck 2009). Sexual morality is significant evidence of this erosion; there is a clear estrangement between the norms and institutional orientations and people's behavior, but this does not produce any crisis of faith or belonging. Beliefs taught by the official ecclesial doctrine follow a similar process, as shown by the experiences shared by the interviewee sand-covered in the previous pages.

Related to religious affiliation, the appearance of sui generis phrases can also be seen as a sign of religious autonomy in Latin America. However, this tendency is not found in the interviews conducted in the BAC, i.e., we find no evidence of religious hybridization practices that link different religious traditions. The religious self-adscription of Catholics and Evangelicals that are part of the Latin American community living in the BAC seems to be clearly defined.

With respect to religious practice, Evangelicals attend services more frequently than Catholics both in America and in the BAC. This may well be due to the style of the ecclesial community and the emotional ties that are created within the Evangelical churches. In the case of immigrants, their condition as migrants may explain the need expressed during interviews for warm and friendly personal relationships, which may be more easily established as a result of the lifestyle of the Evangelical communities. As attending liturgical celebration differs depending on personal affiliation, the practice 
of prayer (more directly related to personal experience) seems to be widely shared. Among other personal religious practices, it is worth noting that the Latin American population living in the BAC shows a certain use of religious images that indicates, to some extent, the reworking of their spiritual experience. Nevertheless, the use of these symbols and images is lower than among the population studied in Latin America (Morello 2017, 2019; Morello et al. 2017; Rabbia et al. 2019).

Finally, we want to draw attention to the fact that the processes of religious pluralism and autonomy analyzed in this paper do not run in parallel to each other, unconnected; on the contrary, they mutually condition and imply each other. Being more exposed to religious pluralism offers more alternatives to choose; personal autonomy in choosing between different religious options pluralizes religious developments (Berger 2014). Both processes are often found in the biographies of the interviewees, although formulated differently.

\section{Conclusions}

Given the demographic profile of the Basque population and its level of economic development, it is highly likely that the BAC will receive a significant and increasing migrant flow in the near future together with their own religious traditions. The Latin American population residing in the BAC is the most important immigrant contingent and will foreseeably grow in the immediate future. As reflected in the various quantitative studies available, this population is characterized by a dynamic religious experience that clearly contrasts with the socio-religious data of the indigenous population, which is highly secularized and currently involved in a process that has not yet bottomed out.

Thus, Basque society becomes a privileged vantage point from which to observe the transformation of religion within the context of a developed society. On the one hand, it would seem that the religious shifts of the BAC perfectly matches with the theory of secularization; but, on the other hand, the reality of an emerging religious pluralism (linked to a certain extent to immigration) forces us to rethink the assumed linearity of the secularization process.

Interviews with people who identify themselves as "religious" have shown the processes of autonomy and pluralization of religious life. These processes affect both the Latin American population residing in America and the immigrant population living in the BAC, as well as the native population. When comparing the three groups, several similarities and symmetries appear: (1) The erosion of the institution, mainly among Catholics; (2) the distance between believers and the religious hierarchy, especially regarding the contents of religious beliefs and guidelines concerning bioethical issues; (3) a tendency to rework the spiritual experience (Coupeau 2017 individually).

Nevertheless, a closer analysis of the religious experiences voiced by the interviewees allows us to identify nuances that point out the differences between the three groups. The Latin American population strongly perceives religious pluralism, as well as its vital consequences; however, such perception and experience are almost absent in the autochthonous population, especially among the Catholic population. Likewise, the importance of attending religious worship and the need to establish solid community relationships are most visible in the Evangelical Latin American population. When comparing the Latin American population in America and in the BAC, we observe that the immigrant population: (1) Makes less use of customized religious images; (2) does not expect religion to increase its public presence; (3) shows a lesser degree of religious hybridization.

It seems we have not yet reached the end of the road, but rather we are at the start of a new path. The evidence found raises the question of the process of secularization in Basque society, which has often been regarded as irreversible. The above-noted processes of autonomy and pluralism ask new critical questions of the future developments of religious phenomena. Several uncertainties with no immediate response appear in the light of the results of our analysis, such as: How will the immigrant population transmit inter-generationally its faith? How will the native population evolve its perception of the religious phenomenon and its role in society?

In any case, immigration in general, and more precisely Latin American immigration, raises the question of the mutual influence between religious experience and the socio-cultural context. 
Author Contributions: Conceptualization, L.U. and I.B.; writing—original draft preparation, L.R., L.U., and I.B.; Writing-review, tables, pictures and editing, L.R. All authors have read and agreed to the published version of the manuscript.

Funding: This research received no external funding.

Conflicts of Interest: The authors declare no conflict of interest.

\section{References}

Aierdi, Xabier, Nekane Basabe, Cristina Blanco, and José Antonio Oleaga. 2008. Población latinoamericana en la CAPV 2007. Zarautz: Itxaropena.

Ammerman, Nancy T. 2014. Sacred Stories, Spiritual Tribes. Finding Religion in Everyday Life. New York: Oxford University Press.

Basterretxea, Iziar, Luzio Uriarte, and Gorka Urrutia. 2019. Revisión crítica de algunas variables que miden el fenómeno religioso. In XIII Congreso Español de Sociología. Libro de Actas. Valencia: FES.

Basterretxea, Iziar. 2012. Los valores relacionados con la religión. In Cambio de valores en los inicios del siglo XXI en Euskadi y Navarra. Análisis de las Encuestas Europeas de Valores 1999-2008. Edited by J. Leonardo. Bilbao: Universidad de Deusto.

Bauman, Zygmunt, and Thomas Leoncini. 2018. Generación líquida. Transformaciones en la era 3.0. Barcelona: Paidós.

Beck, Ulrich. 2009. El Dios personal. La individualización de la religión y el "espíritu" del cosmopolitismo. Barcelona: Paidós.

Beck, Ulrich, and Elisabeth Beck-Gernsheim. 2003. La individualización: El individualismo institucionalizado y sus consecuencias sociales y políticas. Barcelona: Paidós.

Beckford, James A., and Thomas Luckmann. 1991. The Changing Face of Religion. London: Sage.

Berger, Peter L. 1969. The Sacred Canopy. Elements of Sociological Theory of Religion. New York: Anchor.

Berger, Peter L. 2014. The Many Altars of Modernity. Toward a Paradigm for Religion in a Pluralistic Age. Boston: Walter de Gruyter.

Bericat, Eduardo. 2008. El escepticismo religioso y secular en Europa. In El fenómeno religioso. Presencia de la religión y de la religiosidad en las sociedades avanzadas. Edited by Eduardo Bericat. Sevilla: Centro de Estudios Andaluces, pp. 41-56.

Bruce, Steve. 2002. God is Dead: Secularization in the West. Oxford: Blackwell.

Chaves, Mark. 2010. Rain dances in the dry season: Overcoming the religious congruence fallacy. Journal for the Scientific Study of Religion 49: 1-14. [CrossRef]

Coupeau, José Carlos. 2017. Religión, fe, teología y espiritualidad. Estudios Eclesiásticos 92: 369-385.

Da Costa, Néstor. 2003. Religión y sociedad en el Uruguay del siglo XXI. Un estudio de la religiosidad en Montevideo. Montevideo: Centro Unesco de Montevideo.

Da Costa, Néstor. 2008. Guía de la diversidad religiosa en Montevideo. Montevideo: Taurus.

Davie, Grace. 1994. Religion in Britain since 1945: Believing without Belonging. Oxford: Blackwell.

Davie, Grace. 2013. The Sociology of Religion: A Critical Agenda. London: Sage.

Davie, Grace, and Danièle Hervieu-Léger. 1996. Identités religieuses en Europe (Recherches). Paris: La Découverte.

Day, Abby. 2013. Believing in Belonging: Belief and Social Identity in the Modern World. Oxford: Oxford University Press.

Duch, Lluis. 2015. Antropología de la ciudad. Barcelona: Herder.

Elzo, Javier. 2017. Morir para renacer. Otra Iglesia posible en la era global y plural. Madrid: San Pablo.

Estrada, Juan Antonio. 2001. Razones y sinrazones de la creencia religiosa. Madrid: Trotta.

Eusko Jaurlaritza. 2012. Diversidad religiosa. Vitoria-Gasteiz: EUSTAT.

EUSTAT. 2018. Panorama demográfico 2018. Vitoria-Gasteiz: EUSTAT.

Gauchet, Marcel, and Luc Ferry. 2007. Lo religioso después de la religión. Barcelona: Anthropos.

González-Anleo, Juan, and José Antonio López-Ruiz. 2017. Jóvenes españoles entre dos siglos 1984-2017. Madrid: SM.

Hagopian, Frances, ed. 2009. Religious Pluralism, Democracy, and the Catholic Church in Latin America. Notre Dame: University of Notre Dame.

Hervieu-Léger, Danièle. 2016. La religión, hilo de memoria. Madrid: Herder. 
Ikuspegi. 2018. Barómetro 2018. Percepciones y actitudes hacia la población de origen extranjero. Vitoria-Gasteiz: Observatorio Vasco de Inmigración.

Küng, Hans. 2004. El nuevo paradigma de las relaciones internacionales y el papel de las religiones. In Interculturalidad, diálogo interreligioso y liberación. Edited by Juan José Tamayo and Raúl Fornet-Betancourt. Estella: Verbo Divino, pp. 17-30.

Ladeur, Karl-Heinz. 2014. The myth of the neutral state and the individualization of religion: Relationship between state and religion in the face of fundamentalism. In Constitutional Secularism in an Age of Religious Revival. Edited by Susanna Mancini and Michel Rosenfeld. Oxford: Oxford University Press, pp. 33-53.

Lenoir, Frederic. 2012. Dios. Barcelona: Kairos.

Levine, Daniel H. 2012. Politics, Religion and Society in Latin America. London: Lynne Rienner Publishers.

Longo, Oskar, Miren Bilbao, and Nieves Corcuera. 2017. Euskadiko gazteak 2016. Vitoria-Gasteiz: Eusko Jaurlaritzaren Argitalpen Zerbitu Nagusia.

Fortunato Mallimaci, director. 2013, Atlas de las creencias religiosas en Argentina. Buenos Aires: Biblos.

Mallimaci, Fortunato. 2015. El mito de la Argentina laica. Catolicismo, política y estado. Buenos Aires: Capital Intelectual.

Mardones, José María. 1988. Postmodernidad y cristianismo. El desafío del fragmento. Estella: Verbo Divino.

Mardones, José María. 1994. Para comprender las nuevas formas de la religión. La reconfiguración postcristiana de la religión. Estella: Verbo Divino.

Mardones, José María. 2003. La vida del símbolo. La dimensión simbólica de la religión. Santander: Sal Terrae.

Marzal, Manuel M., Catalina Romero, and José Sánchez, eds. 2000. La religión en el Perú al filo del milenio. Lima: Fondo Editorial.

Marzal, Manuel M., Catalina Romero, and José Sánchez, eds. 2004. Para entender la religión en el Perú 2003. Lima: Fondo Editorial.

McGuire, Meredith B. 2008. Lived Religion. Faith and Practice in Everyday Life. New York: Oxford University Press.

Morello, Gustavo. 2017. Modernidad y religiosidad en América Latina. Razón y Fe 276: 327-338.

Morello, Gustavo, Catalina Romero, Hugo H. Rabbia, and Néstor da Costa. 2017. An enchanted modernity: Making sense of Latin America's religious landscape. Critical Research on Religion 5: 308-326. [CrossRef]

Morello, Gustavo. 2019. Imágenes de Dios en la ciudad. In La religión como experiencia cotidiana: Creencias, prácticas y narrativas espirituales en Sudamérica. Edited by Hugo Rabbia, Gustavo Morello, Nestor Da Costa and Catalina Romero. Lima: Fondo Editorial, pp. 99-108.

Morondo, Dolores, and Eduardo J. Ruiz Vieytez. 2014. Diversidad religiosa, integración social y acomodos. Un análisis desde la realidad local en el caso vasco. Brussels: Peter Lang.

Narvaiza, José Luis, and Jon Paul Laka. 2002. La religiosidad. In Los valores de los vascos. Edited by Javier Elzo. Bilbao: Universidad de Deusto, pp. 177-225.

Pasquale, Frank L., and Barry A. Kosmin. 2013. Atheism and the secularization thesis. In The Oxford Handbook of Atheism. Edited by S. Bullivant and M. Ruse. Oxford: Oxford University Press, pp. 451-467.

Pérez-Agote, Alfonso. 2004. Cambio religioso en España: Los avatares de la secularización. Madrid: CIS.

Rabbia, Hugo H., Gustavo Morello, Nestor Da Costa, and Catalina Romero. 2019. La religión como experiencia cotidiana: Creencias, prácticas y narrativas espirituales en Sudamérica. Lima: Fondo Editorial.

Rodríguez, Lidia, and Luzio Uriarte. 2016. Religious minorities and access to public space in the Autonomous Community of the Basque Country and in Navarre: The perspective of religious minorities. In Contested Spaces, Common Ground. Edited by Ulrich Winkler, Lidia Rodríguez and O. Leirvik. Leiden: Brill, pp. 243-252.

Romero, Catalina, ed. 2016. Diversidad religiosa en el Perú. Miradas múltiples. Lima: Centro de Estudios y Publicaciones.

Romero, Catalina. 2019. Católicos en Lima: Viviendo encuentros interreligiosos. In La religión como experiencia cotidiana: Creencias, prácticas y narrativas espirituales en Sudamérica. Edited by Hugo H. Rabbia. Gustavo Morello, Nestor Da Costa and Catalina Romero. Lima: Fondo Editorial, pp. 83-92.

Ruiz Vieytez, Eduardo J. 2010. Pluralidades latentes. Minorías religiosas en el País Vasco. Barcelona: Icaria.

Sánchez de la Yncera, Ignacio, and Marta Rodríguez Fooz. 2012. Dialéctica de la postsecularidad. Pluralismo y corrientes de secularización. Barcelona: Anthropos.

Sartori, Giovanni. 2001. La sociedad multiétnica. Pluralismo, multiculturalismo y extranjeros. Taurus: Madrid.

Schlegel, Jean-Louis. 1995. Religions à la carte. París: Hachette. 
Skard, Halvdan. J. Palard, J.M. Woerling, J.F. Husson, J. Mahiels, P. Gaudin, F. Burchianti, X. Itçaina, N. Tietze, and A. Anwar. 2008. Gods in the City. Intercultural and Interreligious Dialogue at Local Level. Wasselone: Council of Europe Publishing.

Stark, Rodney. 1999. Secularization, R.I.P. Sociology of Religion 60: 249-273.

Taylor, Charles. 2015. La era secular. Barcelona: Gedisa.

Touraine, Alain. 1993. Crítica de la modernidad. Madrid: Temas de Hoy.

Touraine, Alain, and Farhad Khosrokhavar. 2002. La búsqueda de sí mismo. Diálogo sobre el sujeto. Barcelona: Paidós. Uriarte, Luzio, and Gorka Urrutia. 2018. Minorías religiosas y centros de culto: Percepción social y problemáticas para la gestión pública. Zerbitzuan: Gizarte zerbitzuetarako aldizkaria 65: 53-64. [CrossRef]

Uriarte, Luzio. 2017. La “no-religión” y su vivencia. Estudos de Religiao 31: 207-231. [CrossRef]

Urrutia, Manuel María. 2010. Religión: Creencias, prácticas e iglesias. In Un individualismo placentero y protegido. Cuarta Encuesta Europea de Valores en su aplicación a España. Edited by Javier Elzo and María Silvestre. Bilbao: Universidad de Deusto, pp. 127-164.

Vattimo, Gianni. 2010. Adiós a la verdad. Barcelona: Gedisa.

Vide, Vicente. 2013. Comunicar la fe en la ciudad secular. Santander: Sal Terrae.

Ward, Graham. 2005. Cultural Transformation and Religious Practice. Cambridge: Cambridge University Press.

(C) 2020 by the authors. Licensee MDPI, Basel, Switzerland. This article is an open access article distributed under the terms and conditions of the Creative Commons Attribution (CC BY) license (http://creativecommons.org/licenses/by/4.0/). 